\title{
Effect of Heat Treatment of Al Substrate on GaN Film Electrodeposited in Aqueous Solution
}

\author{
Jae-Wook Kang ${ }^{*}$, Kensuke Kuroda ${ }^{2}$, Masazumi Okido ${ }^{2}$ \\ ${ }^{1}$ Department of Materials Science \& Engineering, Graduate School of Engineering, Nagoya University, Nagoya, Japan \\ ${ }^{2}$ Institute of Materials and Systems for Sustainability, Nagoya University, Nagoya, Japan \\ Email: *kang.jaewook@a.mbox.nagoya-u.ac.jp
}

How to cite this paper: Kang, J.-W., Kuroda, K. and Okido, M. (2020) Effect of Heat Treatment of Al Substrate on GaN Film Electrodeposited in Aqueous Solution. Journal of Surface Engineered Materials and Advanced Technology, 10, 1-19.

https://doi.org/10.4236/jsemat.2020.101001

Received: January 14, 2020

Accepted: January 28, 2020

Published: January 31, 2020

Copyright $\odot 2020$ by author(s) and Scientific Research Publishing Inc. This work is licensed under the Creative Commons Attribution International License (CC BY 4.0).

http://creativecommons.org/licenses/by/4.0/

\section{Open Access}

\begin{abstract}
Most reports on the fabrication of high-quality Gallium nitride $(\mathrm{GaN})$ are typically based on physical techniques that require very expensive equipment. Therefore, the electrodeposition was adopted and examined to develop a simple and economical method for GaN synthesis. GaN films are synthesized on aluminum substrates that are heat-treated at various temperatures using a low-cost and low-temperature electrochemical deposition technique. The electrochemical behavior of source ions in aqueous solutions is examined by cyclic voltammetry $(\mathrm{CV})$. In the solution at $\mathrm{pH} 1.5$ containing $0.1 \mathrm{M}$ $\mathrm{Ga}\left(\mathrm{NO}_{3}\right)_{3}, 2.5 \mathrm{M} \mathrm{NH}_{4} \mathrm{NO}_{3}$ and $0.6 \mathrm{M} \mathrm{H}_{3} \mathrm{BO}_{3}$, reduction of gallium and nitrate ions are observed in $\mathrm{CV}$. The presence of hexagonal $\mathrm{GaN}$ and gallium oxide $\left(\mathrm{Ga}_{2} \mathrm{O}_{3}\right)$ phases is detected for the films deposited on $\mathrm{Al}$ substrates at -3.5 $\mathrm{mA} \cdot \mathrm{cm}^{-2}$ for $3 \mathrm{~h}$. The energy dispersive X-ray and mapping results reveal that $\mathrm{Ga}, \mathrm{O}$, and $\mathrm{N}$ coexist in these films. Raman analysis shows hexagonal GaN formation on $\mathrm{Al}$ substrates. The changes in the morphology and preferred orientation of $\mathrm{GaN}$ were found, which was caused by the reactivity of aluminum surface and the aluminum oxide layer formed by the heat treatment.
\end{abstract}

\section{Keywords}

Gallium Nitride, Electrochemical Deposition, Growth from Aqueous Solutions, Aluminum Substrates

\section{Introduction}

Gallium nitride $(\mathrm{GaN})$ is one of the most promising III-V semiconductor materials that use nitrogen as a group V element [1] [2] [3] [4] [5]. In particular, GaN has been recognized to be the most important material for blue and ultraviolet optoelectronic devices and has recently attracted considerable attention after the 
successful fabrication of high-efficiency blue light-emitting diodes [6] [7] [8] [9]. During the last two decades, numerous studies have been conducted on GaN semiconductors, and several reports have been published on the synthesis technology of these semiconductors [10]-[19]. Various dry plating methods, such as metal-organic chemical vapor deposition (MOCVD) [20] [21], molecular beam epitaxy (MBE) [22] [23] [24], thermal ammoniation [25], physical vapor deposition [26], and chemical vapor deposition [27] [28] [29], have been adopted and used in many researches. However, the high cost of these equipments is one of the major challenges to be overcome for commercialization and widespread application. Moreover, the use of high-temperature systems and ultra-pure gases for GaN fabrication entails considerable complexity and additional manufacturing cost [30].

Therefore, the electrodeposition has recently been proposed as one of low temperature and low-cost synthesis methods of semiconductor materials, and has been studied by some researchers as an alternative for $\mathrm{GaN}$ synthesis. Several reports have also confirmed the possibility of $\mathrm{GaN}$ synthesis by electrodeposition [31]-[37]. Most low-temperature GaN syntheses have been conducted on silicon ( $\mathrm{Si}$ ) substrate because of their high quality, large size, and low cost. However, Si and deposited metal usually exhibit a weak interaction that leads to three-dimensional island-like growth or Volmer-Weber mechanism [38] [39]. This is because the rate of electrochemical reaction on $\mathrm{Si}$ is slower than on metals [40].

The substrate effect of various aluminum compounds, such as aluminum nitride (AlN) [41] [42], aluminum gallium nitride (AlGaN) [43] [44] and aluminum oxide $\left(\gamma-\mathrm{Al}_{2} \mathrm{O}_{3}\right)$ [45], which can improve the crystallinity of $\mathrm{GaN}$, has been studied and reported by many researchers [46] [47]. High-quality GaN have been grown on Al-based intermediate layers. It can be considered that $\mathrm{Al}$ plays an important role in GaN growth. In particular, it can be expected to be more suitable as substrate material for fabrication of GaN film in wet processes since $\mathrm{Al}$ has better conductivity than $\mathrm{Si}$.

Therefore, the synthesis of $\mathrm{GaN}$ film was performed on $\mathrm{Al}$ substrate in this study. In addition, the effect of heat treatment of $\mathrm{Al}$ substrate on the $\mathrm{GaN}$ formation was investigated.

\section{Experimental Details}

\subsection{Materials and Reagents}

For electrodeposition, a commercial Al plate (99.9\% purity) and Pt coil (99.99\% purity) are purchased and used as working and counter electrodes, respectively. Gallium nitrate hydrate $\left(\mathrm{Ga}\left(\mathrm{NO}_{3}\right)_{3} \cdot \mathrm{xH}_{2} \mathrm{O}, \geq 99.9 \%\right.$, Sigma Aldrich) and ammonium nitrate $\left(\mathrm{NH}_{4} \mathrm{NO}_{3}, \geq 98 \%\right.$, Sigma Aldrich) are used as sources of $\mathrm{Ga}$ and $\mathrm{N}$, respectively. Boric acid $\left(\mathrm{H}_{3} \mathrm{BO}_{3}, \geq 99.5 \%\right.$, Sigma Aldrich) is purchased and employed to prepare the electroplating electrolyte as a surfactant and a buffer. Concentrated nitric acid $\left(\mathrm{HNO}_{3}, 70.0 \%\right.$, Nacalai Tesque) is used to adjust the $\mathrm{pH}$ 
level of each solution. Deionized water with a resistivity of $18.2 \mathrm{M} \Omega \cdot \mathrm{cm}$ is used in all the experiments.

\subsection{Electrode Preparation}

The working electrodes are $1.0 \times 1.0 \mathrm{~cm}^{2} \mathrm{Al}$ plates with a $99.9 \%$ purity, and a $\mathrm{Pt}$ coil is used as counter electrode. An Ag|AgCl|sat'd- $\mathrm{KCl}$ electrode is employed as reference electrode. The $\mathrm{Al}$ substrates are prepared by polishing using emery paper to a grade of 2000. They are ultrasonically cleaned with ethanol for 10 min, followed by deionized water for another $10 \mathrm{~min}$. The Pt coil is immersed in hydrochloric acid ( $\mathrm{HCl}, 35 \%$, Nacalai Tesque) to clean the surface and is thereafter washed with distilled water. Finally, all electrodes are washed with distilled water and dried under atmospheric conditions. Prior to electrodeposition, the Al plate is covered with a Nitoflon adhesive tape (Nitto Denko) to yield an electrode area of $0.5 \times 0.5 \mathrm{~cm}^{2}$.

\subsection{Heat Treatment of Al Substrates}

The influence of electrode conditions, such as the composition and crystallinity of various electrodes, on material synthesis has been widely investigated [48]. Here, the $\mathrm{Al}$ substrates are prepared to examine the influence of $\mathrm{Al}$ oxide layer on the synthesis of GaN film by electrodeposition. Since Al can form gamma phase alumina at $500^{\circ} \mathrm{C}$ or higher, heat treatment was performed at $200^{\circ} \mathrm{C}$ and $500^{\circ} \mathrm{C}$ for $1 \mathrm{~h}$. The $\mathrm{Al}$ substrates, referred to as $\mathrm{Al} 200 \mathrm{HT}$ and $\mathrm{Al} 500 \mathrm{HT}$, are heat-treated at $200^{\circ} \mathrm{C}$ and $500^{\circ} \mathrm{C}$ for $1 \mathrm{~h}$, respectively, in an atmospheric electric furnace according to the commercial Al plate used. The oxide formation and crystallinity of each Al substrate are characterized by SEM and XRD.

\subsection{Electrodeposition Process}

All the electrochemical depositions are performed using a potentiostat (Hokuto Denko, HA3003A) in a three-electrode cell configuration at atmospheric pressure and temperature of $25^{\circ} \mathrm{C}$. As shown by the E-pH diagram of $\mathrm{Ga}$ in Figure (a) [49], gallium ion $\left(\mathrm{Ga}^{3+}\right)$ exists in the form of passivated gallium oxide $\left(\mathrm{Ga}_{2} \mathrm{O}_{3}\right)$ or gallium hydroxide $\left(\mathrm{Ga}(\mathrm{OH})_{3}\right)$ in a solution with a $\mathrm{pH}$ level of 3 or more. Thus, all electrochemical experiments are performed from acidic solutions at $\mathrm{pH}$ 1.5. The electrodeposition is conducted in acidic solutions composed of $0.1 \mathrm{M}$ of $\mathrm{Ga}\left(\mathrm{NO}_{3}\right)_{3}, 2.5 \mathrm{M}$ of $\mathrm{NH}_{4} \mathrm{NO}_{3}$, and $0.6 \mathrm{M}$ of $\mathrm{H}_{3} \mathrm{BO}_{3}$. To prevent the abrupt change in the $\mathrm{pH}$ level of the solution by hydrogen ion $\left(\mathrm{H}^{+}\right)$depletion near the electrode surface during the electrodeposition process, $\mathrm{H}_{3} \mathrm{BO}_{3}$ is used as buffer. The electrodepositions are attempted using the galvanostatic method a current density of $3.5 \mathrm{~mA} \cdot \mathrm{cm}^{-2}$ for $3 \mathrm{~h}$. In our previous study, the best results were obtained at this current density [50]. The working and counter electrodes are separated by a distance of approximately $1.0 \mathrm{~cm}$, and the electrolyte is vigorously stirred during the electrodeposition process. After deposition, the specimens are immediately rinsed thoroughly with distilled water. 


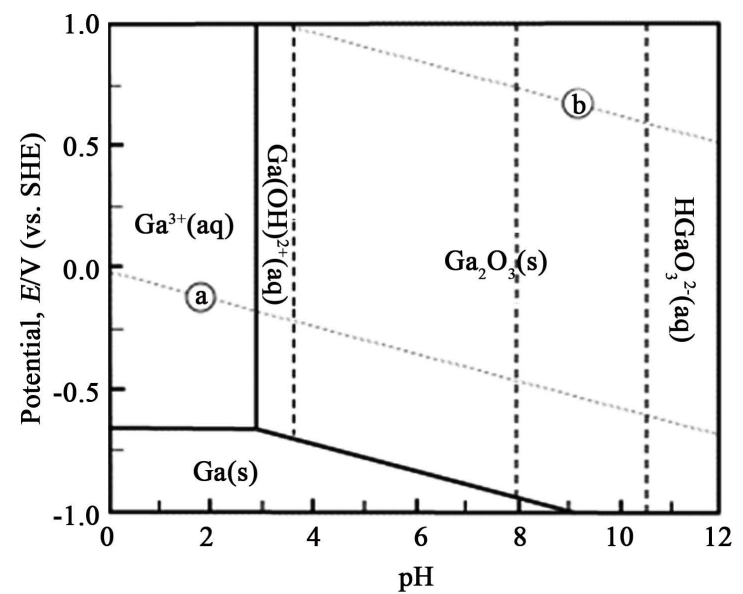

(a)

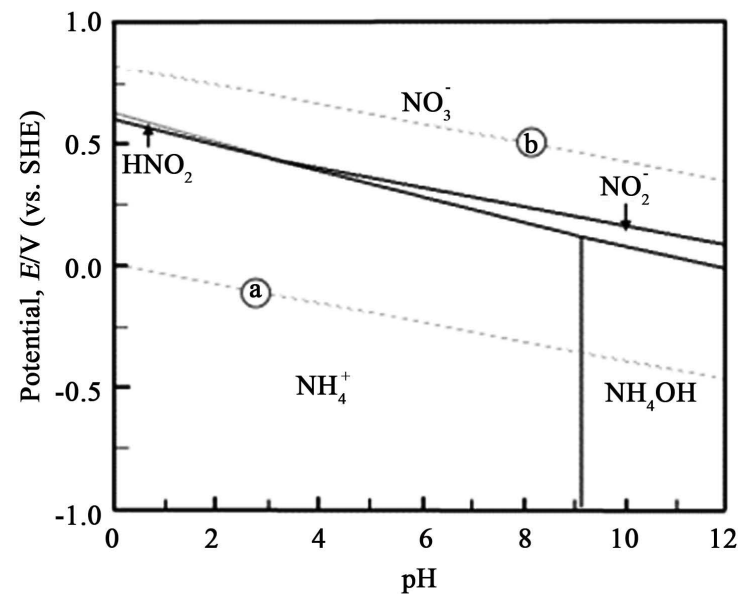

(b)

Figure 1. Potential vs. $\mathrm{pH}$ equilibrium diagrams of (a) gallium and (b) nitrogen in aqueous solution at $25^{\circ} \mathrm{C}$ [modified from ref. 49 and 50, respectively].

\subsection{Characterization and Tests}

The cyclic voltammetry experiments are performed to confirm the electrochemical behavior of each ion on the $\mathrm{Al}$ surface. The current response is recorded against the applied voltage $(\mathrm{V}$ vs. $\mathrm{Ag} / \mathrm{AgCl})$, which is scanned in a triangular waveform.

The surface morphology is characterized with scanning electron microscopy (SEM, Hitachi, S-4800), and the chemical composition is analyzed by energy dispersive X-ray spectroscopy (EDX, HORIBA, EMAX ENERGY, EX-350). The SEM measurement is performed at $10 \mathrm{kV}$, and the EDX analysis is conducted at an acceleration voltage of $12 \mathrm{kV}$ and current of $10 \mu \mathrm{A}$. The crystalline quality and the lattice parameter of the samples are characterized by X-ray diffraction (XRD, Rigaku, Ultima IV) with a $\mathrm{Cu}-\mathrm{K} \alpha_{1}$ radiation source $(\lambda=1.541 \AA$ ). To examine the chemical bonding states, X-ray photoelectron spectroscopy (XPS) measurements are performed with a PerkinElmer PH1 ESCA system. Monochromatic $\mathrm{Mg}-\mathrm{K} \alpha$ ionizing radiation $(1254 \mathrm{eV})$ is used with the $\mathrm{X}$-ray source operating at $300 \mathrm{~W}(15 \mathrm{kV}$ and $20 \mathrm{~mA})$. Raman measurements are performed using 
Horiba Jobin Yvon HR system, and an argon ion laser $(514.5 \mathrm{~nm})$ is utilized as an excitation source. The Raman scattering experiment is implemented in the $z$ $(x$, unpolarized) $\bar{z}$ scattering configuration. The resolution of this system is 1 $\mathrm{cm}^{-1}$, and the integral time is $3000 \mathrm{~ms}$.

\section{Results and Discussion}

\subsection{Electrochemical Behavior of Gallium and Nitrogen Ions}

The CV experiments are performed for aqueous solutions containing several chemicals to examine the electrochemical behavior of ions. The $\mathrm{pH}$ level of all solutions is adjusted by $\mathrm{HNO}_{3}$. Table 1 lists the conditions of solutions used in the $\mathrm{CV}$ experiment. The CVs are recorded at a scan rate of $20 \mathrm{mV} \cdot \mathrm{s}^{-1}$ between -2.0 and $2.0 \mathrm{~V}$ vs. $\mathrm{Ag} / \mathrm{AgCl}$, start from rest potential to negative direction and repeated 5 cycles.

Figure 2 shows the $\mathrm{CV}$ results of $5^{\text {th }}$ cycle. In order to easily compare each cathodic curve, the expanded graphs in the range of -2.0 to $0 \mathrm{~V}$ is displayed in the graph below. In the solution at $\mathrm{pH} 1.5$ containing only $\mathrm{HNO}_{3}$ shown in graph (a), a slight reduction current is observed starting from approximately $-0.6 \mathrm{~V}$, and then a small curve appears at ca. $-1.0 \mathrm{~V}$. From the $\mathrm{HNO}_{3}$ solution, the first curve seems to correspond to hydrogen evolution reaction (HER), and second curve can be regarded as the reduction of nitrate $\left(\mathrm{NO}_{3}^{-}\right)$ion. As confirmed from E-pH diagram of nitrogen $(\mathrm{N})$ in Figure $1(\mathrm{~b})$ [51], $\mathrm{NO}_{3}^{-}$ion can be reduced through the following cathodic reactions.

$$
\begin{aligned}
& \mathrm{NO}_{3}^{-}+2 \mathrm{H}^{+}+2 \mathrm{e}^{-} \rightarrow \mathrm{NO}_{2}^{-}+\mathrm{H}_{2} \mathrm{O} \\
& \mathrm{NO}_{2}^{-}+8 \mathrm{H}^{+}+6 \mathrm{e}^{-} \rightarrow \mathrm{NH}_{4}^{+}+2 \mathrm{H}_{2} \mathrm{O}
\end{aligned}
$$

Although the reduction potential of $\mathrm{NO}_{3}^{-}$ion is very positive than HER, it can be seen that the $\mathrm{NO}_{3}^{-}$ion does not reduce easily before HER. And if the reaction continues, $\mathrm{N}$ species ion may change to most stable ammonium $\left(\mathrm{NH}_{4}^{+}\right)$ ion.

In the graph of Figure 2(b) obtained from the solution containing $\mathrm{NH}_{4} \mathrm{NO}_{3}$, cathodic curves starts at -0.7 and shows two peaks at -1.3 and $-1.7 \mathrm{~V}$. Additional curve compared to the graph obtained in the only $\mathrm{HNO}_{3}$ solution can be expected to the reaction to other nitrogen species by the influence of ammonium

Table 1. Bath conditions for cyclic voltammetry measurement.

\begin{tabular}{cccccc}
\hline \multicolumn{7}{c}{ Concentration of ion (M) } \\
\hline Bath & $\mathrm{Ga}\left(\mathrm{NO}_{3}\right)_{3}$ & $\mathrm{NH}_{4} \mathrm{NO}_{3}$ & $\mathrm{H}_{3} \mathrm{BO}_{3}$ & $\mathrm{HNO}_{3}$ & $\mathrm{pH}$ \\
\hline (a) & - & - & - & 0.032 & 1.50 \\
(b) & - & 2.50 & - & 0.032 & 1.50 \\
(c) & 0.10 & - & - & 0.031 & 1.50 \\
(d) & 0.10 & 2.50 & - & 0.031 & 1.50 \\
(e) & 0.10 & 2.50 & 0.60 & 0.029 & 1.50 \\
\hline
\end{tabular}




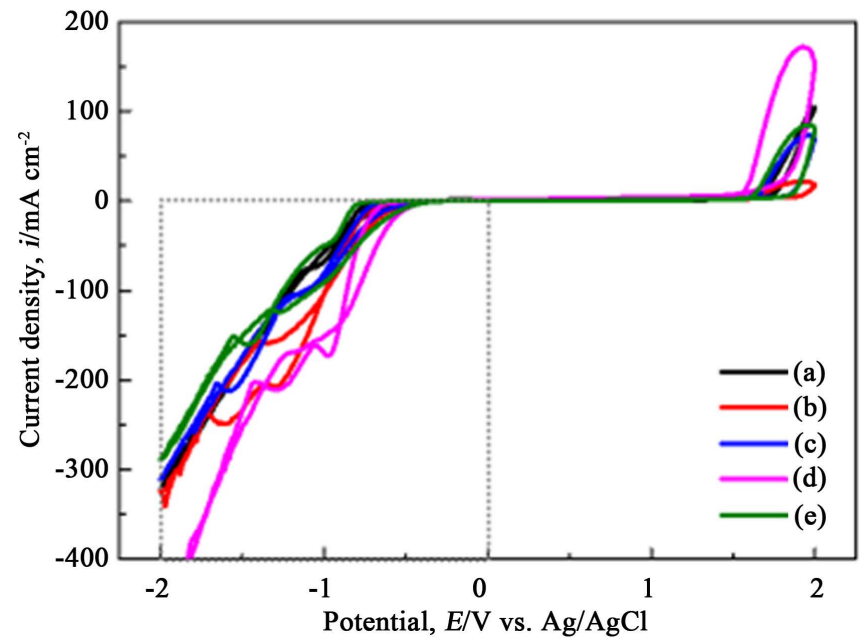

(a)

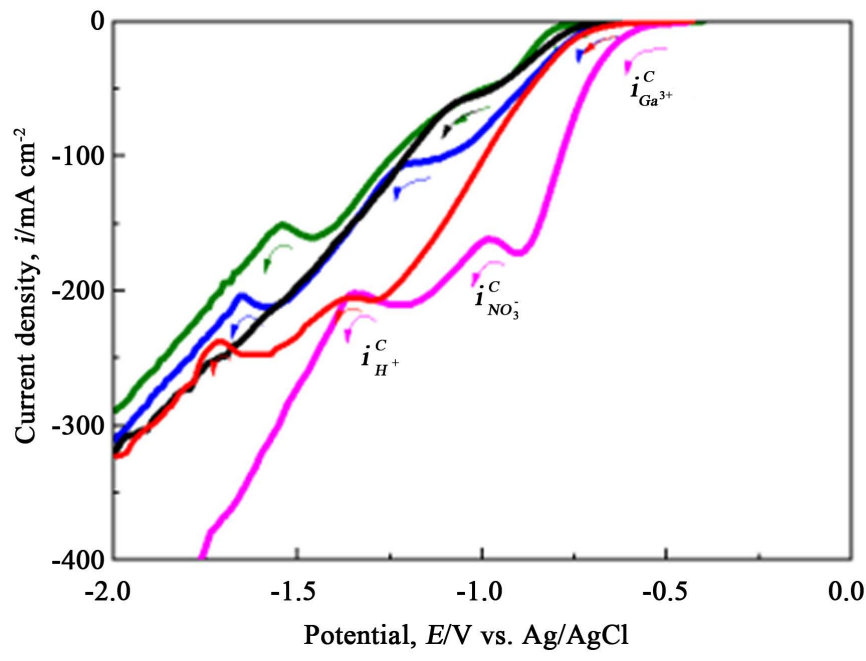

(b)

Figure 2. Comparison of CVs from (a)-(e) aqueous solutions in Table 1. The CVs are recorded at a scan rate of $20 \mathrm{mV} \cdot \mathrm{s}^{-1}$ between -2.0 and $2.0 \mathrm{~V}$, start from rest potential to negative direction and repeated 5 cycles. The graph below shows the cathodic current curves corresponding to a potential region of -2 to $0 \mathrm{~V}$.

ion. The electrochemical reactions of $\mathrm{NO}_{3}^{-}$is known to be complex [52].. However, a previous report on the electrodeposited $\mathrm{Cr}$ in the solution containing nitrogen element by $\mathrm{N}$. Ryan et al. found that $\mathrm{NO}_{3}^{-}$ion forms adsorbed nitrogen $\left(\mathrm{N}_{\mathrm{ads}}\right)$ in aqueous solutions during the electrodeposition process [53]. In particular, the large amount of $\mathrm{NH}_{4}^{+}$ion present in this solution may accelerate the formation of $\mathrm{N}_{\text {ads }}$ through a comproportionation reaction with $\mathrm{NO}_{2}^{-}$ion, as follows:

$$
\mathrm{NO}_{2}^{-}+\mathrm{NH}_{4}^{+} \rightarrow \mathrm{N}_{\text {ads }}+2 \mathrm{H}_{2} \mathrm{O}
$$

In a solution containing $0.1 \mathrm{M} \mathrm{Ga}\left(\mathrm{NO}_{3}\right)_{3}$ (graph (c)), the current flow starts at $-0.8 \mathrm{~V}$, and a current hill appears at $-1.1 \mathrm{~V}$. This start point is close to the potential corresponds to reduction from $\mathrm{Ga}^{3+}$ to solid gallium (Ga) in Figure 1(a), 
and a current hill can be considered as a result of the consumption of $\mathrm{Ga}^{3+}$ at the electrode surface. Therefore, the precipitation of Ga may occur on the Al electrode.

$$
\mathrm{Ga}^{3+}+3 \mathrm{e}^{-} \rightarrow \mathrm{Ga}_{\text {ads }}
$$

It is generally known that hydrogen discharge is preferred for $\mathrm{Ga}$ deposition, thus the reduction reaction of $\mathrm{Ga}^{3+}$ can therefore occur after the HER on the cathode surface [54]. The curve appearing at $-1.7 \mathrm{~V}$ thereafter corresponds to the reduction reaction of $\mathrm{NO}_{3}^{-}$of Equation (1) and Equation (2). That is, even if $\mathrm{Ga}$ is adsorbed on the $\mathrm{Al}$ substrate, the reduction reaction of $\mathrm{NO}_{3}^{-}$ion can occur, and it can be expected that the reaction of $\mathrm{NO}_{3}^{-}$ion occurs at a more negative potential under the influence of the adsorbed gallium $\left(\mathrm{Ga}_{\mathrm{ads}}\right)$.

In the graph (d) obtained from a solution containing $\mathrm{Ga}^{3+}, \mathrm{NO}_{3}^{-}$and $\mathrm{NH}_{4}^{+}$ ions, three clearly separated cathodic peaks appear. After the large current peak corresponding to the precipitation of $\mathrm{Ga}, i_{\mathrm{Ga}}^{c}$, a distinct reduction peak is found at the potential region corresponding to the formation of $\mathrm{N}_{\mathrm{ads}}, i_{\mathrm{N}_{\mathrm{ads}}}^{c}$, confirmed from graph (b). In addition, the increased and separated current peak with the addition of $\mathrm{Ga}^{3+}$ ion indicates the formation of new phase precipitates on the $\mathrm{Al}$ substrate. During the reactions of Equations (3) and (4) on the $\mathrm{Al}$ surface, $\mathrm{N}_{\mathrm{ads}}$ can be combined with $\mathrm{Ga}_{\text {ads }}$ and finally forms clusters to form $\mathrm{GaN}$ layer.

$$
\mathrm{Ga}_{\text {ads }}+\mathrm{N}_{\mathrm{ads}} \rightarrow \mathrm{GaN}
$$

Clusters of critical sizes are formed, subsequently leading to the growth of continuous films. These Ga-N bonds cause $\mathrm{Ga}$ and $\mathrm{N}$ to have electronic states of trivalent $\mathrm{Ga}$ cations $\left(\mathrm{Ga}^{3+}\right)$ and trivalent $\mathrm{N}$ anions $\left(\mathrm{N}^{3-}\right)$, respectively, resulting in secondary growth of $\mathrm{GaN}$ with $\mathrm{Ga}^{3+}$ and $\mathrm{NH}_{4}^{+}$ions in the solution.

$$
\begin{gathered}
\mathrm{Ga}^{3+}+\mathrm{NH}_{4}^{+}+4 \mathrm{e}^{-} \rightarrow \mathrm{GaN}+2 \mathrm{H}_{2} \\
\mathrm{Ga}^{3+}+\mathrm{N}^{3-} \rightarrow \mathrm{GaN}
\end{gathered}
$$

The third current may be considered to correspond to the reduction of $\mathrm{H}^{+}$ion caused by the consumption of $\mathrm{NH}_{4}^{+}$ion, $i_{\mathrm{H}^{+}}^{c}$.

When $\mathrm{H}_{3} \mathrm{BO}_{3}$ is added (graph (e)), the current density decreases, and the amount of hydrogen gas bubbles generated on the $\mathrm{Al}$ surface is reduced, and also the bubble size becomes smaller. Boric acid thus acts as a surface agent and may be expected to function as a buffer to retard the generation rate of hydrogen ion $\left(\mathrm{H}^{+}\right)$as well as prevent hydrogen adsorption, which can interfere with the permeation of $\mathrm{N}$ source ion on the $\mathrm{Al}$ surface [54].

\subsection{Heat Treatment of Al Substrates}

Figure 3 shows the XRD spectra of $\mathrm{Al}$ samples heat-treated at different temperatures. Four main diffraction peaks are observed at $2 \theta$ values of 38.5, 44.8, 65.1, and 78.3 degrees, corresponding to the reflections of $\mathrm{Al}$ (111), $\mathrm{Al}$ (200), $\mathrm{Al}$ (220), and $\mathrm{Al}(311)$ in the $\mathrm{Al}$ plate (Figure 3(a)). In the XRD results of heat-treated $\mathrm{Al}$ samples (Figure 3(b) and Figure 3(c)), the diffraction patterns indicate the existence of gibbsite $\left(\mathrm{Al}(\mathrm{OH})_{3}\right)$ and gamma $(\gamma)$ phase of alumina $\left(\mathrm{Al}_{2} \mathrm{O}_{3}\right)$ on the $\mathrm{Al}$ 


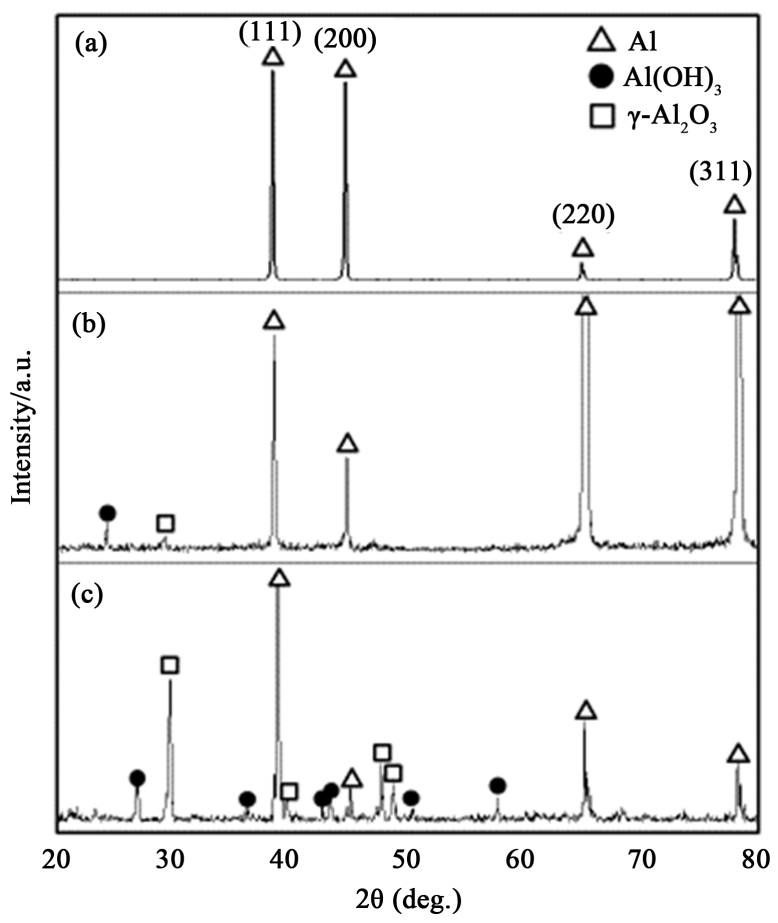

Figure 3. XRD spectra of $\mathrm{Al}$ plates heat-treated at different temperature; (a) Free; (b) $200^{\circ} \mathrm{C}$ for $1 \mathrm{~h}$; (c) $500^{\circ} \mathrm{C}$ for $1 \mathrm{~h}$.

surface. In the $\mathrm{Al} 200 \mathrm{HT}$ sample, a peak corresponding to $\mathrm{Al}(\mathrm{OH})_{3}$ and very small peaks due to $\gamma-\mathrm{Al}_{2} \mathrm{O}_{3}$ are detected at $2 \theta=24.3$ and 29.6 degrees, respectively. The peaks caused by the reflection of $\gamma-\mathrm{Al}_{2} \mathrm{O}_{3}$ are strongly observed at $2 \theta$ $=29.6,39.8$, and 47.7 degrees, and the small peaks due to the reflection of $\alpha-\mathrm{Al}_{2} \mathrm{O}_{3}$ are observed at $2 \theta=26.8,35.6,48.6$, and 50.3 degrees for the Al500HT sample. The XRD pattern also confirms that no additional contamination exists on the $\mathrm{Al}$ samples.

Figure 4 shows SEM images of three $\mathrm{Al}$ sample surfaces. On the surface of the Al plate before heat treatment, oxide-form particles do not appear, but large plate-like particles are observed on the Al200HT sample. In the Al500HT sample, it is found that the spherical particles with an average diameter of $1.2 \mu \mathrm{m}$, which are generally observed from $\gamma-\mathrm{Al}_{2} \mathrm{O}_{3}$ are distributed [55].

\subsection{Electrodeposition and Characterization}

The electrodeposition of $\mathrm{GaN}$ film in an aqueous solution is attempted on $\mathrm{Al}$ substrates, and their morphology and composition are characterized by SEM and EDX. Figure 5 shows the SEM images of GaN films deposited with a current density of $-3.5 \mathrm{~mA} \mathrm{~cm}^{-2}$ for $3 \mathrm{~h}$ in the solution corresponds to Table 1(e). And the corresponding EDX analysis data are summarized in Table 2. The films obtained from Table 1(c) solution without $\mathrm{NH}_{4}^{+}$ion, $\mathrm{N}$ was not detected, and more than $40 \mathrm{~mol} \% \mathrm{O}$ was detected in the films electrodeposited from Table 1(d) solution via EDX. Therefore, this paper describes the films electrodeposited from Table 1(e) solution. 

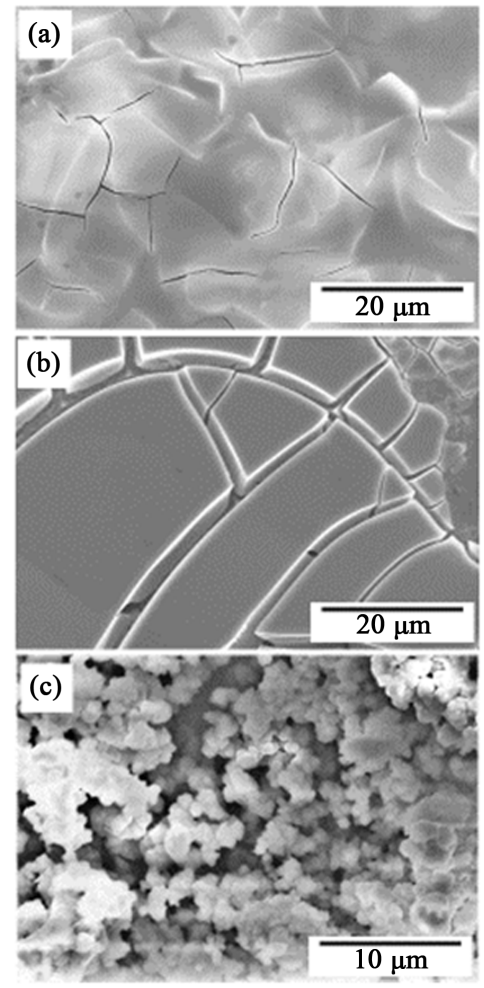

Figure 4. SEM images of the surface of $\mathrm{Al}$ samples heat-treated at different temperature; (a) Free; (b) $200^{\circ} \mathrm{C}$ for $1 \mathrm{~h}$; (c) $500^{\circ} \mathrm{C}$ for $1 \mathrm{~h}$.
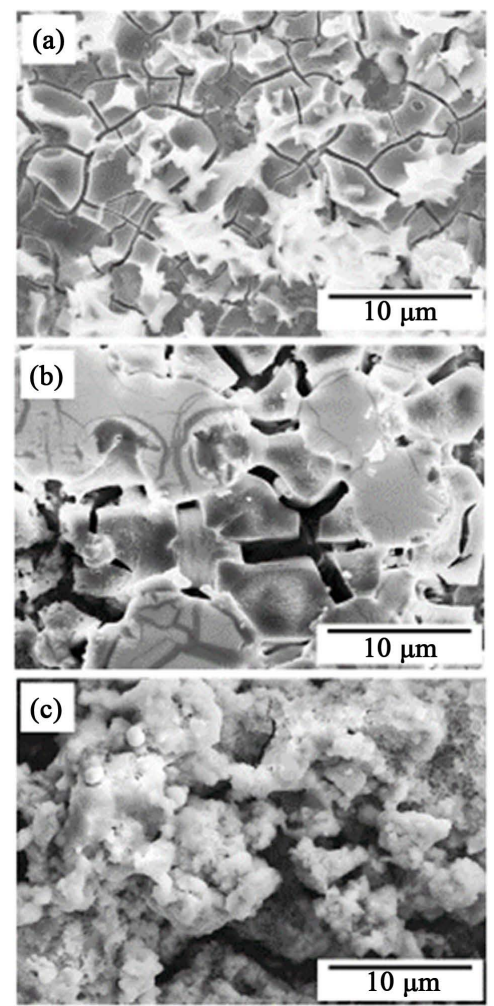

Figure 5. SEM images of the films deposited at $3.5 \mathrm{~mA} \cdot \mathrm{cm}^{-2}$ for $3 \mathrm{~h}$ on (a) Al plate; (b) Al200HT; (c) Al500HT. And the enlarged images are shown on the right. 
Table 2. EDX results of the films deposited on $\mathrm{Al}$ substrates at $-3.5 \mathrm{~mA} \cdot \mathrm{cm}^{-2}$ for $3 \mathrm{~h}$.

\begin{tabular}{ccccccc}
\hline \multirow{2}{*}{ Element } & \multicolumn{2}{c}{ Al plate } & \multicolumn{2}{c}{ Al200HT } & \multicolumn{2}{c}{ Al500HT } \\
\cline { 2 - 7 } & mass\% & mol\% & mass\% & mol\% & mass\% & mol\% \\
\hline Ga & 68.48 & 35.02 & 69.17 & 33.99 & 36.73 & 14.28 \\
N & 14.87 & 37.85 & 13.60 & 33.27 & 14.67 & 28.40 \\
O & $5 . .64$ & 12.58 & 12.47 & 26.70 & 20.88 & 20.88 \\
$\mathrm{Al}$ & 11.01 & 14.55 & 4.76 & 6.05 & 36.27 & 36.44 \\
\hline
\end{tabular}

As shown in Figure 5, the film formed on the Al plate exhibit an island-like morphology. And the island-like particles are connected and grow in the form of a thick plate for the film deposited on Al200HT (Figure 5(b)). In the film deposited on Al500HT, a cauliflower-like structure, which was found in the $\gamma-\mathrm{Al}_{2} \mathrm{O}_{3}$ or $\beta-\mathrm{Ga}_{2} \mathrm{O}_{3}$ samples, is further formed [55] [56].

The EDX results summarized in Table 2 clearly reveal that more than 35 mol\% of $\mathrm{N}$ and $\mathrm{Ga}$ are present with $\mathrm{O}$ in the $\mathrm{GaN}$ film grown on the $\mathrm{Al}$ substrate. This indicates that the GaN compound film is formed according to Equation (6). The mapping micrographs of Figure 6 clearly reveal the presence of Ga and $\mathrm{N}$ on the $\mathrm{Al}$ substrate. These elements are uniformly dispersed in the deposited films. Similarly, the N content is more than $28 \mathrm{~mol} \%$ at any given position in the films that form on Al200HT and Al500HT. On the other hand, oxygen increases by more than $20 \mathrm{~mol} \%$, which can be attributed to $\gamma-\mathrm{Al}_{2} \mathrm{O}_{3}$. The mapping results in Figure 6 also show that the films containing a large amount of $\mathrm{N}$ are formed on the $\mathrm{Al}$ substrates, and $\mathrm{Ga}, \mathrm{N}$ and $\mathrm{O}$ coexist.

Figure 7 shows the XRD spectra of GaN films that are prepared by electrodeposition. Two peaks that correspond to the reflection of $\mathrm{h}-\mathrm{GaN}$ are observed at $2 \theta=32.7^{\circ}$ and $36.8^{\circ}$; these peaks are caused by reflections from the $(1 \overline{1} 00)$ and (10 $\overline{1} 1$ ) planes for the film deposited on the Al plate, respectively [57] [58]. In contrast, a strong peak corresponding to the reflection of (0002) plane is detected at $2 \theta=34.4^{\circ}$ in the diffraction result for the film deposited on Al200HT (Figure 7(b)). In the film formed on Al500HT (Figure 7(c)), the peaks caused by the reflection of $\mathrm{h}-\mathrm{GaN}$ at the three aforementioned positions are detected, and the peak corresponding to the reflection of the h-GaN ( $1 \overline{1} 00)$ plane appears to be the strongest. The strong peaks at $2 \theta=38.1^{\circ}$ and $2 \theta=45.4^{\circ}$ are caused by reflections from $\mathrm{Al}(111)$ and (200), respectively, and a peak at $2 \theta=29.3^{\circ}$ is caused by the reflection of $\gamma-\mathrm{Al}_{2} \mathrm{O}_{3}$. The weak intensity peaks corresponding to $\mathrm{Ga}$ and $\beta-\mathrm{Ga}_{2} \mathrm{O}_{3}$ are also confirmed. Based on the XRD measurement of all samples, it can be observed that the h-GaN film is formed under the experimental conditions used in this study.

The surface of the as-deposited material is characterized by XPS studies. Figure 8 shows the evolution of XPS spectra of Ga $3 d$ and N $1 s$ on the surface of the films. All spectra are deconvoluted using a Gaussian-Lorentzian function with background subtraction. Three main peaks are detected in the spectra of Ga $3 d$ at $18.1,22.4$, and $26.4 \mathrm{eV}$ corresponding to $\mathrm{Ga}, \mathrm{GaN}$, and $\mathrm{Ga}_{2} \mathrm{O}_{3}$, respectively, as 


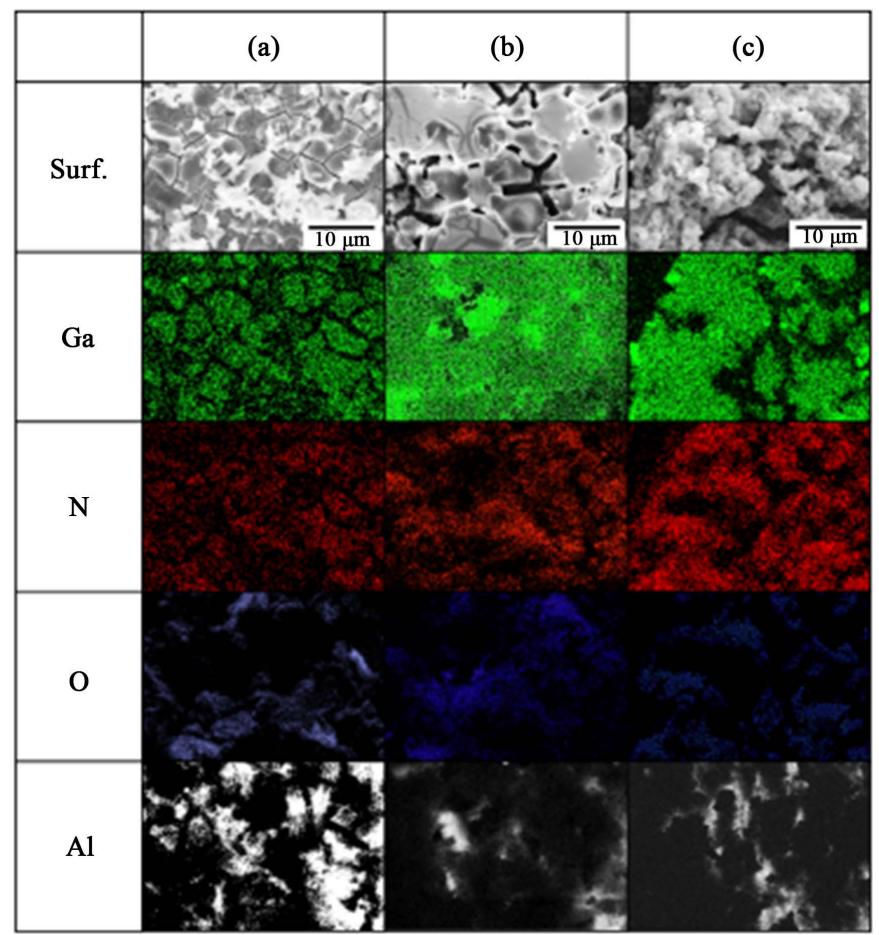

Figure 6. SEM micrographs along with elemental mapping via EDX for $\mathrm{Ga}, \mathrm{O}, \mathrm{N}$ and $\mathrm{Al}$ for the surface of films deposited on (a) Al plate; (b) Al200HT; (c) Al500HT.

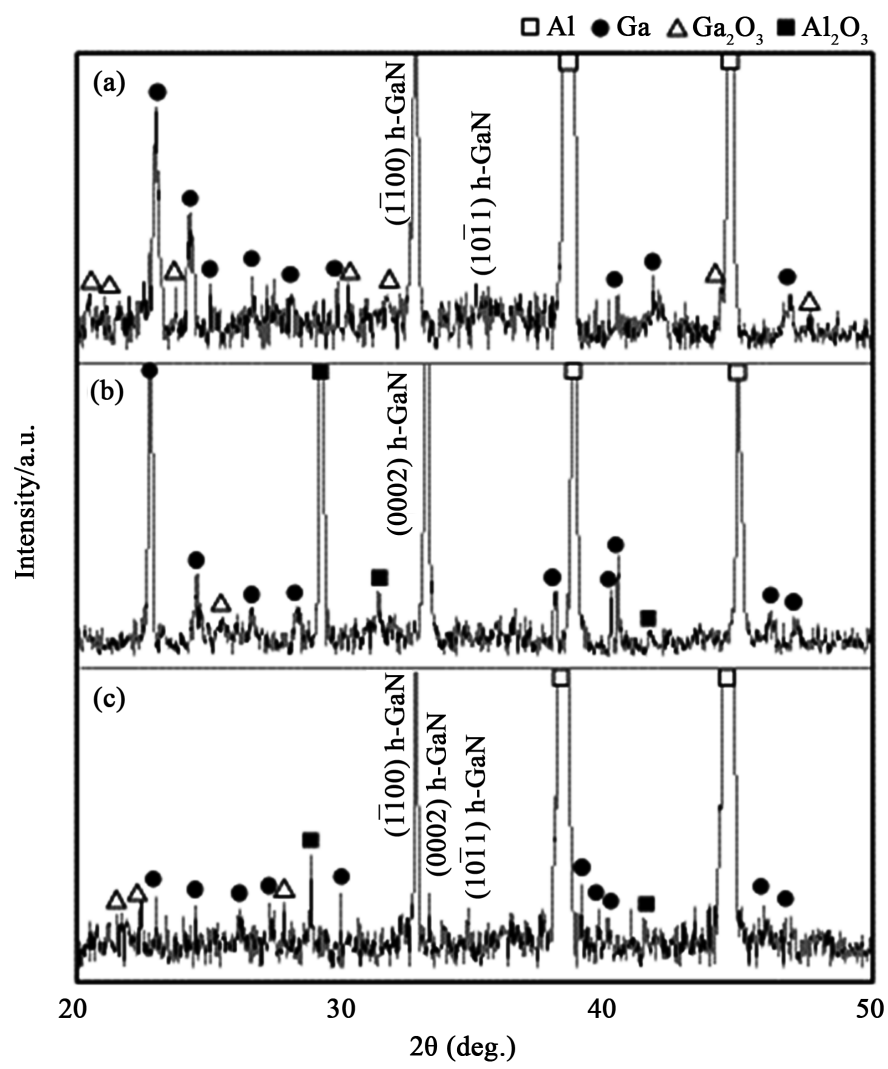

Figure 7. XRD spectra of the films deposited at $3.5 \mathrm{~mA} \cdot \mathrm{cm}^{-2}$ for $3 \mathrm{~h}$ on (a) Al plate; (b) Al200HT; (c) Al500HT. 

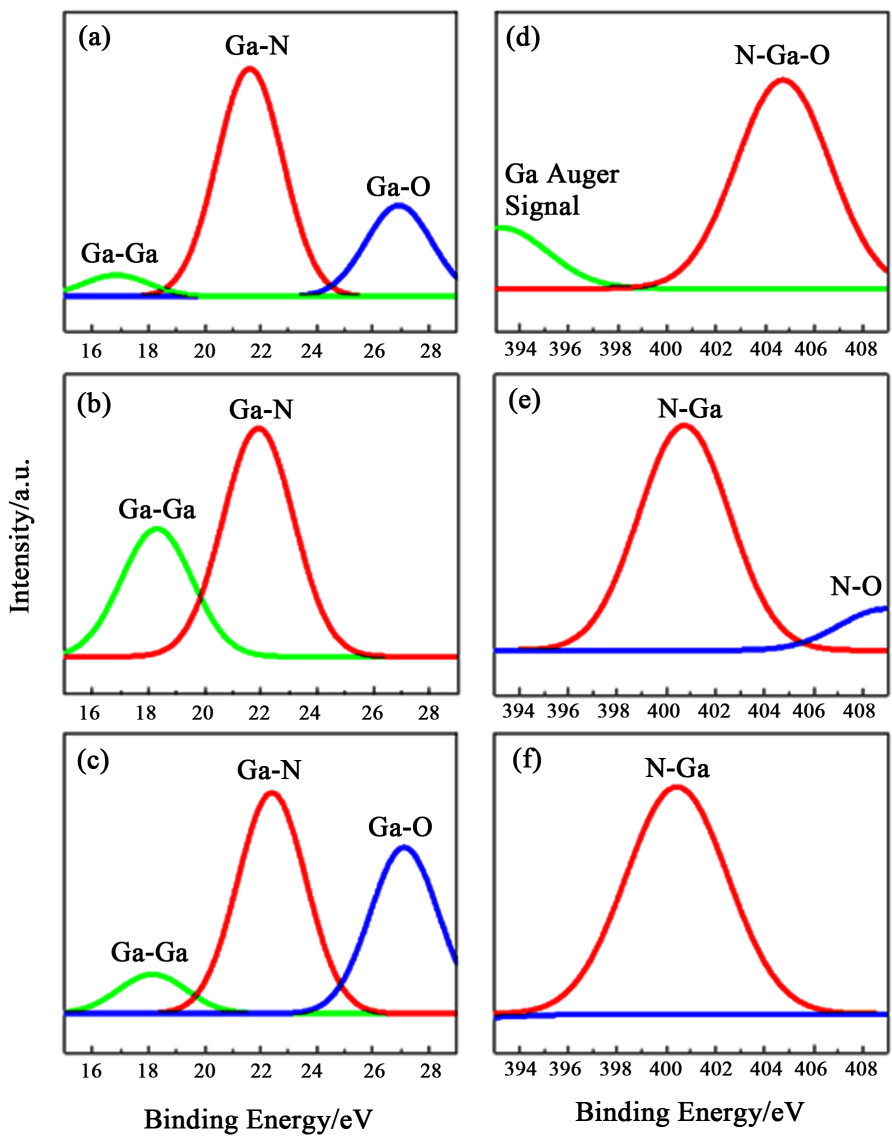

Figure 8. XPS spectra of $\mathrm{Ga} 3 d$ photoelectron peak of GaN films deposited on (a) $\mathrm{Al}$ plate; (b) Al200HT; (c) Al500HT, and the graphs on the right side show N $1 s$ photoelectron peak for the same samples; (d)-(f). (a)-(c) Ga 3d; (d)-(f) N $1 s$.

shown in Figures 8(a)-(c) [59]. These peaks are higher than those observed in $\mathrm{GaN}(\mathrm{Ga} 3 d$ at $19.6 \mathrm{eV}$ ), but three separated peaks corresponding to each chemical bonding are clearly observed [60] [61]. The binding energy of $\mathrm{N} 1 s$ at 399.7 $\mathrm{eV}$ clearly shows the presence of nitride $\left(\mathrm{N}^{3-}\right)$ (Figures $8(\mathrm{e})-(\mathrm{f})$ ), and peaks corresponding to $\mathrm{N}-\mathrm{O}$ bonds appear at a binding energy of $408.6 \mathrm{eV}$ [62]. In the deposited film on the $\mathrm{Al}$ plate without $\mathrm{Al}_{2} \mathrm{O}_{3}$ layer (Figure 8(d)), only peaks corresponding to $\mathrm{N}-\mathrm{Ga}-\mathrm{O}$ bonds appear, and there are no peaks corresponding to Ga-N bonds. Despite the inclusion of $\mathrm{H}_{3} \mathrm{BO}_{3}$ in the electrodeposition solution, there is no detected peak caused by boron in all samples.

Figure 9 shows the Raman spectrum of films deposited on $\mathrm{Al}$ substrates. Three Raman active optical phonon modes corresponding to h-GaN have been observed from GaN film deposited on the Al plate. One mode is at $144 \mathrm{~cm}^{-1}$ because of $\mathrm{E}_{2}(\mathrm{LO})$, and two bands are at 518 and $718 \mathrm{~cm}^{-1}$ of modes $\mathrm{A}_{1}$ (TO) and $\mathrm{E}_{1}$ (LO), respectively [63]. In the film formed on Al200HT, the band that corresponds to $A_{1}(T O)$ is intensified, and the signal at $570 \mathrm{~cm}^{-1}$ that corresponds to $\mathrm{E}_{1}(\mathrm{TO})$ is also detected. In contrast, weak bands are detected from the film deposited on Al500HT because of the influence of a thick oxide layer. As can be observed from Figure 9(b) and Figure 9(c), strong bands corresponding to 


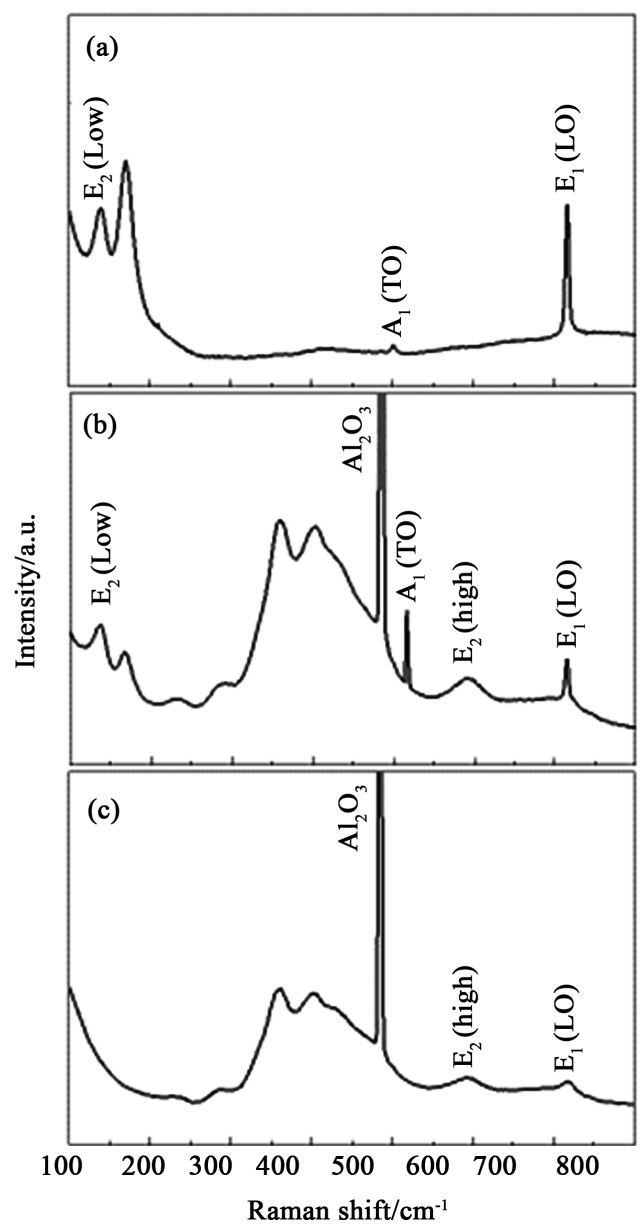

Figure 9. Raman spectroscopy of GaN films deposited at $3.5 \mathrm{~mA}$ for $3 \mathrm{~h}$ on (a) Al plate; (b) Al200HT; (c) Al500HT.

$\mathrm{Al}_{2} \mathrm{O}_{3}$ are also detected in the films deposited on heat-treated $\mathrm{Al}$ substrates. The small bands that appear at 359 and $427 \mathrm{~cm}^{-1}$ may be caused by the acoustic phonons of $\mathrm{Al}_{2} \mathrm{O}_{3}$.

\subsection{Effect of Heat Treatment of Al on GaN Formation}

The effects of the $\mathrm{Al}$ substrate on $\mathrm{GaN}$ formation by electrodeposition are considered. It is confirmed that $\mathrm{Al}(\mathrm{OH})_{3}$ and $\gamma-\mathrm{Al}_{2} \mathrm{O}_{3}$ are detected on the heat-treated $\mathrm{Al}$ samples. The SEM photographs of GaN films on the aforementioned Al substrates show that the film formed on Al200HT substrate has the densest structure. It can be considered that the slight increase in surface energy and oxide formation by heat treatment make it easy to generate the Ga-N combining reaction. However, the formation of a thick $\gamma-\mathrm{Al}_{2} \mathrm{O}_{3}$ layer does not make to improve the crystallinity of the $\mathrm{GaN}$ film and causes $\mathrm{Ga}-\mathrm{O}-\mathrm{Al}$ bonding. The XRD results shown in Figure 7 reveal that there is a difference in the orientation of the $\mathrm{GaN}$ film formed on the three $\mathrm{Al}$ substrates. In other words, it can be seen that the growth of $\mathrm{GaN}$ film is affected by the properties of the surface condition and $\mathrm{Al}_{2} \mathrm{O}_{3}$ layer. 


\section{Conclusions}

The GaN films are synthesized on $\mathrm{Al}$ substrates heat-treated different temperatures by electrodeposition under ambient temperatures. The CV analysis reveals that starting from a potential value that approaches the Ga reduction potential, $\mathrm{NO}_{3}^{-}$ion could be combined by adsorbing $\mathrm{Ga}$ and $\mathrm{O}$ during the deposition process, resulting in the formation of GaN films.

The GaN films are prepared by applying a current density of $-3.5 \mathrm{~mA} \cdot \mathrm{cm}^{-2}$ for $3 \mathrm{~h}$ on $\mathrm{Al}$ substrates heat-treated at different temperatures. The deposited GaN films contain a mixture of $\mathrm{h}-\mathrm{GaN}$ and $\mathrm{Ga}_{2} \mathrm{O}_{3}$ phases. The $\mathrm{GaN}$ film formed on the $\mathrm{Al}$ substrate is found to grow in a different structure depending on the substrate composition. Through EDX analysis, it is confirmed that $\mathrm{Ga}, \mathrm{N}$, and $\mathrm{O}$ are uniformly distributed in the film. Raman analysis, XRD, and XPS are also revealed the presence of $\mathrm{h}-\mathrm{GaN}$. The GaN film grown on Al200HT having a very thin $\mathrm{Al}$ oxide exhibits the property closest to that of the single crystal h-GaN. The grown GaN films exhibit different growth characteristics depending on the composition and surface energies of $\mathrm{Al}$ substrates.

The GaN films produced in this work contain a considerable amount of $\mathrm{O}$ and exhibit insufficient crystallinity compared to single-crystal GaN. After the formation of $\mathrm{GaN}$, additional processing, such as annealing at a high temperature in the presence of ammonia, may be required, because the addition of $\mathrm{O}$ to the GaN film may cause lattice deformation or diminish material properties. Nevertheless, the possibility of synthesizing $\mathrm{GaN}$ on $\mathrm{Al}$ substrate using a low-cost temperature method that can replace the current expensive process has been confirmed. The fact that GaN films can be formed on metals other than semiconductors will have many advantages for various potential applications.

\section{Acknowledgements}

We appreciate the assistance offered by M. Osada and E. Yamamoto of Nagoya University with experiments for Raman measurement. This work was financially supported by the Grant-in-Aid for Challenging Exploratory Research (No. 16K14447) from the Japan Society for the Promotion of Science (JSPS).

\section{Conflicts of Interest}

The authors declare no conflicts of interest regarding the publication of this paper.

\section{References}

[1] Nakamura, S., Mukai, T. and Senoh, M. (1994) Candela-Class High-Brightness InGaN/AlGaN Double-Heterostructure Blue-Light-Emitting Diodes. Applied Physics Letters, 64, 1687-1689. https://doi.org/10.1063/1.111832

[2] Nakamura, S., Mukai, T. and Senoh, M. (1994) High-Brightness InGaN/AlGaN Double-Heterostructure Blue-Green-Light-Emitting Diodes. Journal of Applied Physics, 76, 8189-8191. https://doi.org/10.1063/1.357872

[3] Khan, M.A., Chen, Q., Skogman, R.A. and Kuznia, J.N. (1995) Violet-Blue GaN 
Homojunction Light Emitting Diodes with Rapid Thermal Annealed p-Type Layers. Applied Physics Letters, 66, 2046-2047. https://doi.org/10.1063/1.113687

[4] Molnar, R.J., Singh, R. and Moustakas, T.D. (1995) Blue-Violet Light Emitting Gallium Nitride p-n Junctions Grown by Electron Cyclotron Resonance-Assisted Molecular Beam Epitaxy. Applied Physics Letters, 66, 268-270.

https://doi.org/10.1063/1.113513

[5] Pankove, J.I. (1973) Luminescence in GaN. Journal of Luminescence, 7, 114-126. https://doi.org/10.1016/0022-2313(73)90062-8

[6] Strite, S. and Morkoç, H. (1992) GaN, AlN, and InN: A Review. Journal of Vacuum Science \& Technology B: Microelectronics and Nanometer Structures Processing, Measurement, and Phenomena, 10, 1237-1266. https://doi.org/10.1116/1.585897

[7] Nakamura, S. (1997) III-V Nitride Based Light-Emitting Devices. Solid State Communications, 102, 237-248. https://doi.org/10.1016/S0038-1098(96)00722-3

[8] Nakamura, S., Senoh, M. and Mukai, T. (1993) High-Power InGaN/GaN Double-Heterostructure Violet Light Emitting Diodes. Applied Physics Letters, 62, 2390-2392. https://doi.org/10.1063/1.109374

[9] Jain, S.C., Willander, M., Narayan, J. and Overstraeten, R.V. (2000) III-Nitrides: Growth, Characterization, and Properties. Journal of Applied Physics, 87, 965-1006. https://doi.org/10.1063/1.371971

[10] Akasaki, I. (2004) The Evolution of Blue Light-Emitting Devices and Nitride Semiconductors. IEEJ Transactions on Fundamentals and Materials, 124, 107-113. https://doi.org/10.1541/ieejfms.124.107

[11] Akasaki, I., Amano, H., Kito, M. and Hiramatsu, K. (1999) Photoluminescence of Mg-Doped p-Type GaN and Electroluminescence of GaN p-n Junction LED. Journal of Luminescence, 48-49, 666-670. https://doi.org/10.1016/0022-2313(91)90215-H

[12] Amano, H., Kito, M., Hiramatsu, K. and Akasaki, I. (1989) P-Type Conduction in Mg-Doped GaN Treated with Low-Energy Electron Beam Irradiation (LEEBI). Journal of Applied Physics, 28, 2112-2114. https://doi.org/10.1143/JJAP.28.L2112

[13] Nakamura, S., Mukai, T. and Senoh, M. (1998) High-Power GaN p-n Junction Blue-Light-Emitting Diodes. Journal of Applied Physics, 30, 1998-2001. https://doi.org/10.1143/JJAP.30.L1998

[14] Nakamura, S., Senoh, M., Iwasa, N., Nagahama, S., Yamada, T. and Mukai, T. (1995) Superbright Green InGaN Single-Quantum-Well Structure Light-Emitting Diodes. Applied Physics Letters, 34, 1332-1335.

https://doi.org/10.1143/JJAP.34.L1332

[15] Nakamura, S., Senoh, Nagahama, S., Iwasa, N., Yamada, T., Matsushita, T., Kiyoku, H. and Sugimoto, Y. (1996) InGaN Multi-Quantum-Well-Structure Laser Diodes with Cleaved Mirror Cavity Facets. Journal of Applied Physics, 35, 217-220. https://doi.org/10.1143/JJAP.35.L217

[16] Nakamura, S., Senoh, Nagahama, S., Iwasa, N., Yamada, T., Matsushita, T., Kiyoku, H. and Sugimoto, Y. (1996) InGaN Multi-Quantum-Well Structure Laser Diodes Grown on $\mathrm{MgAl}_{2} \mathrm{O}_{4}$ Substrates. Journal of Applied Physics, 68, 2105-2107. https://doi.org/10.1063/1.115599

[17] Talwar, D.N., Sofranko, D., Mooney, C. and Tallo, S. (2002) Elastic, Structural, Bonding, and Defect Properties of Zinc-Blende BN, AlN, GaN, InN and Their Alloys. Materials Science and Engineering: B, 90, 269-277. https://doi.org/10.1016/S0921-5107(01)00939-4

[18] Funato, M., Ueda, M., Kawakami, Y., Narukawa1, Y., Kosugi, T., Takahashi, M. and 
Mukai, T. (2006) Blue, Green, and Amber InGaN/GaN Light-Emitting Diodes on Semipolar \{11-22\} GaN Bulk Substrates. Journal of Applied Physics, 45, 659-662. https://doi.org/10.1143/JJAP.45.L659

[19] Nakamura, S., Isawa, N., Senoh, M. and Mukai, T. (1992) Hole Compensation Mechanism of P-Type GaN Films. Journal of Applied Physics, 31, 1258-1266. https://doi.org/10.1143/JJAP.31.1258

[20] Jung, W.G., Jung, S.H., Kung, P. and Razeghi, M. (2006) Fabrication of GaN Nanotubular Material Using MOCVD with an Aluminium Oxide Membrane. Nanotechnology, 17, 54-59. https://doi.org/10.1088/0957-4484/17/1/010

[21] Saidi, C., Chaaben, N., Bchetnia, A., Fouzri, A., Sakly, N. and El Jani, B. (2013) Growth of Scandium Doped GaN by MOVPE. Superlattices and Microstructures, 60, 120-128. https://doi.org/10.1016/j.spmi.2013.05.010

[22] Park, Y.S., Kang, T.W. and Taylor, R. (2008) Abnormal Photoluminescence Properties of GaN Nanorods Grown on Si (111) by Molecular-Beam Epitaxy. Nanotechnology, 19, 1-5. https://doi.org/10.1088/0957-4484/19/47/475402

[23] Kim, W., Aktas, O., Botchkarev, A.E., Salvador, A., Mohammad, S.N. and Morkoc, H. (1996) Reactive Molecular Beam Epitaxy of Wurtzite GaN: Materials Characteristics and Growth Kinetics. Journal of Applied Physics, 79, 7657-7666.

https://doi.org/10.1063/1.362430

[24] Bao, K., Wang, L., Sun, H., Guo, R. and Wu, Y. (2013) Synthesis of GaN Cauliflowers by Ammoniating $\mathrm{Ga}_{2} \mathrm{O}_{3}$. Journal of Alloys and Compounds, 552, 26-30. https://doi.org/10.1016/j.jallcom.2012.10.093

[25] Xue, S., Zhang, X., Huang, R., Tian, D., Zhuang, H. and Xue, C. (2008) A Simple Method for the Growth of High-Quality GaN Nanobelts. Materials Letters, 62, 2743-2745. https://doi.org/10.1016/j.matlet.2008.01.031

[26] Saron, K. and Hashim, M. (2013) Broad Visible Emission from GaN Nanowires Grown on n-Si (111) Substrate by PVD for Solar Cell Application. Superlattices and Microstructures, 56, 55-63. https://doi.org/10.1016/j.spmi.2012.12.020

[27] Tang, Y., Chen, Z., Song, H., Lee, C., Cong, H., Cheng, H., Zhang, W., Bello, I. and Lee, S. (2008) Vertically Aligned p-Type Single-Crystalline GaN Nanorod Arrays on n-Type Si for Heterojunction Photovoltaic Cells. Nano Letters, 8, 4191-4195. https://doi.org/10.1021/nl801728d

[28] Abdullah, Q.N., Yam, F.K., Hassan, Z. and Bououdina, M. (2012) Growth and Conversion of $\beta-\mathrm{Ga}_{2} \mathrm{O}_{3}$ Nanobelts into GaN Nanowires via Catalyst-Free Chemical Vapor Deposition Technique. Superlattices and Microstructures, 54, 215-224. https://doi.org/10.1016/j.spmi.2012.11.017

[29] Abdullah, Q.N., Yam, F.K., Hassan, J.J., Chin, C.W., Hassan, Z. and Bououdina, M. (2013) High Performance Room Temperature GaN-Nanowires Hydrogen Gas Sensor Fabricated by Chemical Vapor Deposition (CVD) Technique. International Journal of Hydrogen Energy, 38, 14085-14101. https://doi.org/10.1016/j.ijhydene.2013.08.014

[30] Iskandar, F., Ogi, T. and Okuyama, K. (2006) Simple Synthesis of GaN Nanoparticles from Gallium Nitrate and Ammonia Aqueous Solution under a Flow of Ammonia Gas. Materials Letters, 60, 73-76. https://doi.org/10.1016/j.matlet.2005.07.075

[31] Sprenger, J.K., Cavanagh, A.S., Sun, H., Wahl, K.J., Roshko, A. and George, S.M. (2016) Electron Enhanced Growth of Crystalline Gallium Nitride Thin Films at Room Temperature and $100{ }^{\circ} \mathrm{C}$ Using Sequential Surface Reactions. Chemistry of Materials, 28, 5282-5294. https://doi.org/10.1021/acs.chemmater.6b00676

[32] Roy, R.K. and Pal, A.K. (2005) Electrodeposition of Gallium in the Presence of 
$\mathrm{NH}_{4} \mathrm{Cl}$ in an Ionic Liquid: Hints for GaN Formation. Materials Letters, 59, 2204-2209. https://doi.org/10.1016/j.matlet.2005.02.067

[33] Al-Heuseen, K., Hashim, M.R. and Ali, N.K. (2010) Synthesis of Hexagonal and Cubic GaN Thin Film on Si (111) Using a Low-Cost Electrochemical Deposition Technique. Materials Letters, 64, 1604-1606. https://doi.org/10.1016/j.matlet.2010.04.043

[34] Qaeed, M.A., Ibrahim, K., Saron, K.M.A. and Salhin, A. (2013) Cubic and Hexagonal GaN Nanoparticles Synthesized at Low Temperature. Superlattices and Microstructures, 64, 70-77. https://doi.org/10.1016/j.spmi.2013.08.015

[35] Al-Heuseen, K. and Hashim, M.R. (2011) One-Step Synthesis of GaN Thin Films on Si Substrate by a Convenient Electrochemical Technique at Low Temperature for Different Durations. Journal of Crystal Growth, 324, 274-277. https://doi.org/10.1016/j.jcrysgro.2011.03.051

[36] Al-Heuseen, K. (2016) Synthesis of GaN Thin Film Using a Low-Cost Electrochemical Deposition Technique for Hydrogen Gas Sensing. International Journal of Thin Films Science and Technology, 5, 113-119. https://doi.org/10.18576/ijtfst/050206

[37] Sarkar, S. and Sampath, S. (2016) Ambient Temperature Deposition of Gallium Nitride/Gallium Oxynitride from a Deep Eutectic Electrolyte, under Potential Control. Chemical Communications, 52, 6407-6410. https://doi.org/10.1039/C6CC02487D

[38] Huang, Q., Deligianni, H. and Romankiw, L.T. (2006) Electrodeposition of Gold on Silicon Nucleation and Growth Phenomena. Journal of the Electrochemical Society, 153, 332-336. https://doi.org/10.1149/1.2183947

[39] Budevski, E., Staikov, G. and Lorenz, W.J. (1996) Electrochemical Phase Formation and Growth. Wiley VCH, Weinheim, 294-297.

https://doi.org/10.1002/9783527614936

[40] Ogata, Y.H., Kobayashi, K. and Motoyama, M. (2006) Electrochemical Metal Deposition on Silicon. Current Opinion in Solid State \& Materials Science, 10, 163-172. https://doi.org/10.1016/j.cossms.2007.02.001

[41] Amano, H., Sawaki, N., Akasaki, I. and Toyoda, Y. (1986) Metalorganic Vapor Phase Epitaxial Growth of a High Quality GaN Film Using an AlN Buffer Layer. Applied Physics Letters, 48, 353-354. https://doi.org/10.1063/1.96549

[42] Chena, P., Zhang, R., Zhao, Z.M., Xia, D.J., Shen, B., Chen, Z.Z., Zhou, Y.G., Xie, S.Y., Lu, W.F. and Zheng, Y.D. (2001) Growth of High Quality GaN Layers with AlN Buffer on Si (111) Substrates. Journal of Crystal Growth, 225, 150-154. https://doi.org/10.1016/S0022-0248(01)00842-9

[43] Huang, C.C., Chang, S.J., Chuang, R.W., Lin, J.C., Cheng, Y.C. and Lin, W.J. (2010) GaN Grown on Si (111) with Step-Graded AlGaN Intermediate Layers. Applied Surface Science, 256, 6367-6370. https://doi.org/10.1016/j.apsusc.2010.04.018

[44] Kim, M.H., Do, Y.G., Kang, H.C., Noh, D.Y. and Park, S.J. (2001) Effects of Step-Graded $\mathrm{Al}_{x} \mathrm{Ga}_{1-x} \mathrm{~N}$ Interlayer on Properties of GaN Grown on Si (111) Using Ultrahigh Vacuum Chemical Vapor Deposition. Applied Physics Letters, 79, 2713-2715. https://doi.org/10.1063/1.1412824

[45] Wang, L., Liu, X., Zan, Y., Wang, J., Wang, D., Lu, D. and Wang, Z. (1998) Wurtzite GaN Epitaxial Growth on a $\mathrm{Si}(001)$ Substrate Using $\gamma-\mathrm{Al}_{2} \mathrm{O}_{3}$ as an Intermediate Layer. Applied Physics Letters, 72, 109-111. https://doi.org/10.1086/311781

[46] Cheng, K., Leys, M., Degroote, S., Germain, M. and Borghs, G. (2008) High Quality GaN Grown on Silicon (111) Using a Interlayer by Metal-Organic Vapor Phase Epitaxy. Applied Physics Letters, 92, Article ID: 192111. https://doi.org/10.1063/1.2928224 
[47] Wu, C.L., Wang, J.C., Chan, M.H., Chen, T.T. and Gwo, S. (2003) Heteroepitaxy of $\mathrm{GaN}$ on $\mathrm{Si}$ (111) Realized with a Coincident-Interface AlN $/ \beta-\mathrm{Si}_{3} \mathrm{~N}_{4}(0001)$ Double-Buffer Structure. Applied Physics Letters, 83, 4530-4532. https://doi.org/10.1063/1.1629384

[48] Akiyama, M., Nagao, K., Ueno, N., Tateyama, H. and Yamada, T. (2004) Influence of Metal Electrodes on Crystal Orientation of Aluminum Nitride Thin Films. Vacuum, 74, 699-703. https://doi.org/10.1016/j.vacuum.2004.01.052

[49] Takeno, N. (2005) Atlas of Eh-pH Diagrams. Intercomparison of Thermodynamic Databases. National Institute of Advanced Industrial Science and Technology, Tsukuba, 153-155.

[50] Kang, J.W., Mitsuhashi, T., Kuroda, K. and Okido, M. (2019) Low-Temperature Synthesis of GaN Film from Aqueous Solution by Electrodeposition. Journal of Applied Electrochemistry, 49, 871-881. https://doi.org/10.1007/s10800-019-01327-w

[51] Pourbaix, M.J.N. (1949) Thermodynamics of Dilute Aqueous Solutions. Edward Arnold and Co., London.

[52] Cubicciotti, D. (1989) Equilibrium Chemistry of Nitrogen and Potential-pH Diagrams for the Fe-Cr- $\mathrm{H}_{2} \mathrm{O}$ System in BWR Water. Journal of Nuclear Materials, 167, 241-248. https://doi.org/10.1016/0022-3115(89)90447-9

[53] Ryan, N. and Lumley, E.J. (1959) The Source of the Nitrogen Impurity in Electrodeposited Chromium. Journal of The Electrochemical Society, 106, 388-391. https://doi.org/10.1149/1.2427365

[54] Gabe, D.R. (1997) The Role of Hydrogen in Metal Electrodeposition Processes. Journal of Applied Electrochemistry, 27, 908-915. https://doi.org/10.1023/A:1018497401365

[55] Segal, F.M., Correa, M.F., Bacani, R., Castanheira, B., Politi, M.J., Brochsztain, S. and Triboni, E.R. (2018) A Novel Synthesis Route of Mesoporous $\gamma$-Alumina from Polyoxohydroxide Aluminum. Materials Research, 21, 1-8. https://doi.org/10.1590/1980-5373-mr-2017-0674

[56] Tsuda, T., Nohira, T. and Ito, Y. (2002) Nucleation and Surface Morphology of Aluminum-Lanthanum Alloy Electrodeposited in a $\mathrm{LaCl}_{3}$-Saturated $\mathrm{AlCl}_{3}$-EtMeImCl Room Temperature Molten Salt. Electrochimica Acta, 47, 2817-2822. https://doi.org/10.1016/S0013-4686(02)00168-8

[57] Huang, E., Li, J., Wu, G., Dai, W., Guan, N. and Li, L. (2017) A Simple Synthesis of $\mathrm{Ga}_{2} \mathrm{O}_{3}$ and GaN Nanocrystals. RSC Advances, 7, 47898-47903. https://doi.org/10.1039/C7RA10639D

[58] Boo, J.H., Ustin, S.A. and Ho, W. (1998) Growth of Hexagonal GaN Thin Films on $\mathrm{Si}$ (111) with Cubic SiC Buffer Layers. Journal of Crystal Growth, 189-190, 183-188. https://doi.org/10.1016/S0022-0248(98)00222-X

[59] Yang, C.C., Lo, I., Hsu, Y.C. and Yang, H.Y. (2017) GaN and InN Hexagonal Microdisks. In: Zhong, M., Ed., Epitaxy, IntechOpen, London, Chap. 7. https://doi.org/10.5772/intechopen.70120

[60] Fang, Z.L., Kang, J.Y. and Shen, W.Z. (2008) Surface Modification and Significant Reduction of Yellow/Blue Luminescence of Gallium Nitride. The Journal of Physical Chemistry C, 112, 17652-17656. https://doi.org/10.1021/jp806202n

[61] Hu, C.C. and Teng, H. (2010) Gallium Oxynitride Photocatalysts Synthesized from $\mathrm{Ga}(\mathrm{OH})_{3}$ for Water Splitting under Visible Light Irradiation. The Journal of Physical Chemistry C, 114, 20100-20106. https://doi.org/10.1021/jp1070083

[62] Song, Y.P., Zhang, H.Z., Lin, C., Zhu, Y.W., Li, G.H., Yang, F.H. and Yu, D.P. 
(2004) Luminescence Emission Originating from Nitrogen Doping of $\beta-\mathrm{Ga}_{2} \mathrm{O}_{3} \mathrm{Na}$ nowires. Physical Review B: Condensed Matter and Materials Physics, 69, Article ID: 075304. https://doi.org/10.1103/PhysRevB.69.075304

[63] Harima, H. (2002) Characterization of GaN and Related Nitrides by Raman Scattering. Journal of the Society of Materials Science, Japan, 51, 983-988.

https://doi.org/10.2472/jsms.51.983 